\title{
Adverse events related to the use of enteral nutritional therapy
}

\author{
Eventos adversos relacionados ao uso de terapia nutricional enteral
}

Eventos adversos en relación con el uso de la nutrición terapia enteral

\author{
Anamarta Sbeghen Cervo ${ }^{a}$ \\ Tânia Solange Bosi de Souza Magnagob \\ Jéssica Baldissera Carolloc \\ Bruna Pereira Chagas ${ }^{d}$ \\ Adriano Silva de Oliveirae \\ Janete de Souza Urbanetto $f$
}

D0l: $\quad$ http://dx.doi.org/10.1590/1983-

1447.2014.02.42396

\footnotetext{
${ }^{a}$ Master in Nursing. Technical-administrative Nurse Coordinator of the Multi-professional Nutritional Therapy Team for the Hospital Universitário de Santa Maria (EMTN/HUSM). Santa Maria, RS, Brazil.

${ }^{b}$ Doctor of Nursing. Professor for the Nursing Department and Post-Graduate Program at the Universidade Federal de Santa Maria (UFSM). Santa Maria, RS, Brazil.

'Nursing Student. Scientific Initiation Scholarship Winner (PROBIC/FAPERGS/UFSM). Santa Maria, RS, Brazil.

${ }^{d}$ Nursing Student. Scholarship Winner at FIEX/UFSM. Santa Maria, RS, Brazil.

e Nursing Student. Scientific Initiation Scholarship Winner FIPE Jr./UFSM. Santa Maria, RS, Brazil.

f Doctor of Health Sciences. Adjunct Professor of the Nursing Course at FAENFI/PUCRS. Porto Alegre, RS, Brazil.
}

\begin{abstract}
Aimed at verifying the occurrence of adverse events related to enteral nutrition use in patients of a public hospital in the countryside of Rio Grande do Sul. A quantitative, longitudinal and descriptive study, conducted in January-May 2012, that accompanied 46 patients admitted to the Intensive Care Unit and Medical Clinic. For evaluating the adverse events, we used quality indicators: inadvertent exit, tube obstruction and volume of infused diet. For analysis, we used descriptive statistics. The results showed that inadvertent exit of the tube and obstruction presented incidence rates of $4.6 \%$ and $2.1 \%$, respectively. The volume of diet infused was less than that prescribed, due to pauses for body hygiene, tests and procedures, nausea / vomiting and delay in the availability of installation of the bottle in the unit. We conclude that the use of quality indicators in the assessment of care can help reduce damage to the patient. Descriptors: Nursing. Enteral nutrition. Quality indicators, healthcare. Patient safety.
\end{abstract}

\section{RESUMO}

Objetivou-se verificar a ocorrência de eventos adversos relacionados ao uso de nutrição enteral em pacientes de um hospital público do interior do Rio Grande do Sul. Estudo quantitativo, longitudinal e descritivo, realizado de janeiro a maio de 2012, com acompanhamento de 46 pacientes internados nas unidades de Terapia Intensiva e Clínica Médica. Para avaliação dos eventos adversos, utilizaram-se os indicadores de qualidade: saída inadvertida, obstrução da sonda e volume de dieta infundido. Para as análises, utilizou-se a estatística descritiva. Como resultados, a saída inadvertida da sonda e a obstrução apresentaram taxas de incidência de 4,6\% e 2,1\%, respectivamente. 0 volume de dieta infundido foi inferior ao prescrito, por pausa para higiene corporal, exames e procedimentos, náusea/vômito e demora na instalação do frasco por indisponibilidade na unidade. Conclui-se que a utilização de indicadores de qualidade na avaliação da assistência pode auxiliar na redução de danos ao paciente.

Descritores: Enfermagem. Nutrição enteral. Indicadores de qualidade em assistência à saúde. Segurança do paciente.

\section{RESUMEN}

Este estudio evaluó el acontecimiento de eventos adversos relacionados con el uso de la nutrición enteral en pacientes de un hospital público en Rio Grande do Sul. Método: Cuantitativo, longitudinal y descriptivo, llevado a cabo de enero a mayo 2012, con 46 pacientes ingresados en la Unidad de Cuidados Intensivos y Medicina Clínica. Para la evaluación de los eventos adversos utilizado los indicadores de calidad de salida: obstrucción inadvertida de la sonda y el volumen infundido dieta. Para el análisis, se utilizó estadística descriptiva. Ya en los resultados se hizo evidente que la salida de la sonda y la obstrucción inadvertida mostró tasas de incidencia del 4,6\% y 2,1\%, respectivamente. El volumen de la dieta fue menor que el prescrito infundido (mediana 81,4 ml) y la pausa para la higiene corporal, pruebas y procedimientos, náuseas/vómitos y retardo en la disponibilidad de la instalación de la botella en la unidad. Llegamos a la conclusión de que el uso de indicadores de calidad en la evaluación de la atención puede ayudar a reducir el daño al paciente. Descriptores: Enfermería. Nutrición enteral. Indicadores de calidad de la atención de salud. Seguridad del paciente. 


\section{口INTRODUCTION}

Enteral nutrition (EN) is a therapy used for individuals who lack the ability to swallow, in both acute and chronic phases, when the patient cannot get at least $70 \%$ of his or

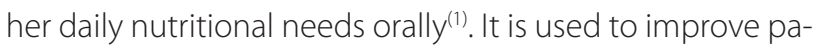
tients' nutritional conditions. Despite efforts made in studies, legislation and debates about the matter, a revival of issues related to patient safety is needed.

One way to evaluate the occurrence of incidents related to Enteral Nutritional Therapy (ENT) is through the use of quality indicators proposed by the International Life Sciences Institute (ILSI)-Brasi|(2) and the Hospital Quality Commitment Program (Programa de Compromisso com a Qualidade Hospitalar $\left.(\mathrm{CQH})^{(3-4)}\right)$. With these indicators, rates of enteral feeding tube (EFT) obstruction, inadvertent exit of the EFT and the dietary volume infused can be evaluated.

The quality indicator of the frequency of inadvertent exit of the EFT seeks to measure the number of tubes accidently lost. Inadvertent exit of the EFT can be considered when it is removed by the actual patient due to psychomotor agitation, use of medication for sedation, mental confusion, neurological disorder or when the patient is being handled for procedures/exams, administering of medication, coughing, nausea/vomiting, bed to stretcher/stretcher to bed transport, or when it is removed by a companion ${ }^{(3-4)}$.

Verification of the frequency of obstruction of the EFT seeks to measure the number of tubes obstructed, assessing their time of use. The enteral infused diet index assesses the ratio of the volume of the diet prescribed to that received during the period.

In Brazil, studies related to patient safety are recent and done mostly approaching the theme of incidents with medications. There is a need for data regarding adverse events related to ENT, which makes this study proposal pertinent to expanding knowledge about this perspective. Already published studies have indicated problems with the administration of enteral diets due to routine procedures with the patient, clinical alterations/complications, the completion of exams and problems related to the feeding tube ${ }^{(5-9)}$. These are situations that may result in adverse events related to the use of EN. The basis for the concept of an adverse event is "an incident that results in harm to the patient" ${ }^{\text {"(10) }}$. These situations need to be better elucidated in the hospital context.

The motivation for the development of this study arose from one of the author's experiences on the Multi-professional Nutritional Therapy Team (EMTN) and, by instituting the study, the goal in its strategic planning is the use of healthcare quality indicators. Therefore, this study contributes to a situational diagnosis related to aspects surrounding ENT, in which the application of quality indicators, seek- ing patient safety, may provide greater visibility for the care given to patients and qualify the care.

Considering the magnitude of the problem presented, the subject of the study is: adverse events related to the use of ENT; and the guiding question is: what are the adverse events related to the use of ENT and how often do they occur with patients hospitalized at the adult ICU and Medical Clinic of the Hospital Universitário de Santa Maria (HUSM)?

Therefore, the objective is to verify the occurrence of adverse events related to the use of enteral nutrition in patients hospitalized at the HUSM.

\section{METHODS}

An exploratory, longitudinal and descriptive study, with a quantitative approach, developed with patients hospitalized at the Adult Intensive Care Unit (Adult ICU) and the Medical Clinic of the HUSM, Rio Grande do Sul, Brasil. The HUSM is a benchmark in high and medium complexity care. The Adult ICU and Medical Clinic have, respectively, nine and 24 beds.

All the adult patients, ages $\geq 18$, using industrialized EN with a closed and continuous system via oro/nasogastric or oro/nasoenteral gastrostomy or jejunostomy feeding tube were included. Patients with ENT that was started after the beginning of the data collection did not participate in the study.

Data was collected from January to May 2012, after approval from the Research Ethics Committee (REC) of the Universidade Federal de Santa Maria (UFSM), under CAAE No. 0354.0.243.000-11, on 12/13/2011. During this period, patients were monitored from the prescription to start ENT until it was suspended, they were discharged from the hospital, or they died.

Data was collected on the patients' medical records, using a form made up of: identification (date of the beginning and end of the data collection, hospitalization unit, bed, date of hospitalization, medical record number); socio-demographic characterization (date of birth, gender, skin color/race, educational level and origin) and the patient's health (diagnosis, feeding tube access route, diet infusion mode, characteristics of the skin at the tube insertion site, time of feeding tube use, hydration, nutritional markers: albumin, hematocrit, hemoglobin); and data referent to the ENT quality indicators suggested by ILSI-Brasi( ${ }^{(2)}$ and $\mathrm{CQH}^{(3-4)}$ (frequency of inadvertent exit of the enteral feeding tube, frequency of obstruction of the enteral feeding tube and infused diet volume).

Data was entered into the 2010 Microsoft Excel Program. After verification of errors and inconsistencies, an analysis of the data was done using the Predictive Analytics Software program, by SPSS Inc., Chicago - USA (PASW Statistics $\left.{ }^{\circledast}\right), 18.0$ for Windows. 
For analysis of the date, descriptive statistics were used. For variables that met the normal distribution, average and standard deviation were used; and, median for those that were not within the bell curve. The categorical variables were described in absolute and relative frequency. The statistical significance was evaluated by the Pearson Chi-squared tests with continuity correction and Fisher's Exact test by Monte Carlo simulation.

To calculate the rate of incidence of adverse events related to the inadvertent exit and obstruction of the feeding tube, the formulas recommended by ILSI-Brasil were used. The targets for inadvertent exit frequency of the feeding tube are $<5 \%$ in the ICUs and $<10 \%$ in hospital units and obstruction frequency of the EFT is $<5 \%(11)$.

For the infused diet volume (estimated prescribed volume - volume received), the average for each patient was calculated according to the days of assessment. Thus, an overall average of the difference of the volume for each patient investigated was obtained. This procedure was also used for the average levels of hematocrit (reference value: men 42 to 52\%, women 36 to 48\%), hemoglobin (reference value: men 13 to $18 \mathrm{~g} / \mathrm{dl}$, women 12 to $16 \mathrm{~g} / \mathrm{dl}$ ) and albumin (reference value: 3.3 to $5.5 \mathrm{~g} / \mathrm{dL}$ ). To evaluate the statistical significance, the Wilcoxon Test was used.

For the number of days of hospitalization of the patients, we used the overall average of days (18.5 days) and average per hospital unit (ICU - 21.6 days and Medical Clinic $=16.2$ days. To investigate the linear relationship between the average difference of the diet volume (estimated - received), the average values of $H T, H B$ and albumin were found using a Spearman Correlation analysis.

\section{RESULTS}

From January to May 2012, 46 patients used ENT at the units investigated. The patients remained hospitalized for at least 3 days and 30 days at the most.

We found a predominance of male patients (71.7\%), between 41 and 80 years old (69.6\%), white (93.6\%), single (51.1\%), who had not completed elementary school (53.2\%), were from Santa Maria (53.2\%) and were hospitalized in the Medical Clinic (55.3\%).

The most frequent diagnoses were related to neurological disorders ( $\mathrm{N}=28)$, especially CVA (32.1\%); respiratory disorders $(\mathrm{N}=12)$, such as pneumonia (41.7\%) and neoplasms ( $N=12)$, with an emphasis on brain tumors (16.7\%). Concurrently, $10.9 \%(\mathrm{~N}=5)$ of patients presented with two diagnoses, and $47.8 \%(\mathrm{~N}=22)$, with three.

When observing access routes for administering EN, the predominant routes were oro/nasogastric $(\mathrm{N}=43 ; 93.5 \%)$, gastronomy ( $N=2 ; 4.4 \%)$ and jejunostomy ( $N=1 ; 2.1 \%)$, with gastric positioning. Infusion of the diet is done through an infusion pump and the skin at the feeding tube insertion site was free of lesions. While the patients were being monitored, no records of incidents related to the feeding tube connection were identified.

The average time of hospitalization in the ICU was 21.6 days, and in the Medical Clinic, 16.2 days. As for the time of use of the EFT diet, 21.7\% ( $N=10)$ of the patients used it for a minimum period of up to nine days; $37 \%(\mathrm{~N}=17)$, between 10 and 20 days; and $41.3 \%(\mathrm{~N}=19)$, for 21 days or longer. The average number of days using the feeding tube for enteral therapy was $18.5( \pm 8.6)$, with at least three days and 30 days at the most.

The rate of incidence for obstruction of the feeding tube was 0.021 for 100 patients using an EFT. At times, we found a lack of a prescription for infusion of water, discontinued prescriptions and standard volume prescriptions. The inadvertent exit of the feeding tube occurred in 43.5\% $(n=20)$ of the patients (Table 2).

39 inadvertent exits were revealed, which corresponds to an incidence rate of $4.6 \%$ [(39/46*18.5)*100]. When we evaluated the number of times that each patient had an inadvertent exit of their feeding tube, we found that in 75\% $(\mathrm{N}=15)$ of the cases, the feeding tube came out a single time; in 10\% ( $N=2)$, twice; in 5\% ( $N=1)$, six times; and in $10 \%(N=2)$, seven times. It is worth emphasizing that the patients who had more than six inadvertent exits of the feeding tube were hospitalized in the Medical Clinic, they were conscious and agitated, and they needed to be mechanically restrained in their beds.

The rates of incidence of inadvertent exit at the Medical Clinic and the ICE were $7.3 \%\left[\left(32 / 27^{*} 16.2\right)^{*} 100\right]$ and $1.7 \%$ $\left[\left(7 / 19^{*} 21.6\right)^{*} 100\right]$, respectively. In Graph 1, the average volumes (estimated, received and difference in 24 hours) per patient on the days evaluated are shown.

The overall average of the difference of the volume of the diet received (estimated - received) was $176.4 \mathrm{ml}$ $( \pm 117.8)$, with a median of $81.4 \mathrm{ml}$, meaning the volume ingested was less than the estimated volume, and in some cases the difference was shown to be statistically significant $(p<0.0001)$. Some of the reasons for suspending the diet include: pause for body hygiene (N-2; 2.4\%), performing exams and procedures ( $N=46 ; 54.8 \%)$, nausea and vomiting ( $\mathrm{N}=29 ; 34.5 \%)$ and unavailability of a new bottle of the diet at the unit ( $\mathrm{N}=7 ; 8.3 \%)$.

As for the hematocrit (HT), hemoglobin ( $\mathrm{HG})$ and albumin evaluation of the patients assessed, we found that for the HT the average was $29.8 \%( \pm 4.5)$, with $4.4 \%(\mathrm{~N}=2)$ of cases with $\mathrm{HT}$ that was higher than or equal to $40.0 \%$; for the HB 
Cervo AS, Magnago TSBS, Carollo JB, Chagas BP, Oliveira AS, Urbanetto JS

Table 1. Distribution of the patients hospitalized in the Adult ICU and Medical Clinic, from January to April 2012, grouped according to socio-demographic characteristics. Santa Maria/RS, 2013 (N=46)

\begin{tabular}{|c|c|c|c|}
\hline \multicolumn{2}{|c|}{ Characteristics } & $\mathbf{N}$ & $\%$ \\
\hline \multirow{2}{*}{ Gender } & Female & 13 & 28.3 \\
\hline & Male & 33 & 71.7 \\
\hline \multirow{7}{*}{ Age range (years) } & 19 to 30 & 6 & 13.0 \\
\hline & 31 to 40 & 2 & 4.3 \\
\hline & 41 to 50 & 8 & 17.4 \\
\hline & 51 to 60 & 8 & 17.4 \\
\hline & 61 to 70 & 8 & 17.4 \\
\hline & 71 to 80 & 8 & 17.4 \\
\hline & 81 to 90 & 6 & 13.0 \\
\hline \multirow{2}{*}{ Skin color/race } & White & 44 & 93.6 \\
\hline & Black/Mixed & 2 & 4.2 \\
\hline \multirow{4}{*}{ Marital status } & Married & 13 & 27.7 \\
\hline & Single & 24 & 51.1 \\
\hline & Separated/Divorced/Widow(er) & 8 & 17.0 \\
\hline & No data & 1 & 2.1 \\
\hline \multirow{5}{*}{ Educational Level } & Illiterate & 2 & 4.3 \\
\hline & Elementary School Incomplete & 25 & 53.2 \\
\hline & Elementary School Completed & 2 & 4.3 \\
\hline & High School Completed & 2 & 4.3 \\
\hline & No data & 15 & 31.9 \\
\hline \multirow{2}{*}{ Origin } & Santa Maria & 25 & 53.2 \\
\hline & Other cities/towns & 19 & 46.8 \\
\hline \multirow{2}{*}{ Hospital unit } & Medical Clinic & 26 & 55.3 \\
\hline & Adult ICU & 20 & 42.6 \\
\hline
\end{tabular}

Source: Research data.

the average was $9.7( \pm 1.6)$, with $8.7 \%(\mathrm{~N}=4)$ of cases with $\mathrm{HB}$ that was higher than or equal to $12 \mathrm{~g} / 100 \mathrm{ml}$. Similarly, for the albumin, the average was $1.93( \pm 0.59)$, and all those investigated presented with levels that were lower than $3.5 \mathrm{~g} / \mathrm{dL}$.

There was no proven correlation between the infused volume with either the $H B(r=0.031 ; p=0.840)$ or the $H T(r=0.016$, $\mathrm{p}=0.916$ ). Therefore, the results of the laboratory exams showed an independent relationship regarding the infused volume of the diet. A similar situation was seen when we compared the average levels of albumin $(r=-0.062 ; p=0.729)$.

\section{DISCUSSION}

The prevalence of patients over 60 converges with the literature, indicating a higher percentage of elderly persons using ENT (60\% e 40\%) $)^{(11-12)}$. Advanced age, combined with an altered state of health requires more attention from professionals, in the sense of preventing, maintaining and controlling possible complications related to ENT ${ }^{(12)}$.

The reasons for hospitalization of the patients on ENT corroborate a study in which the most frequent diagnoses were related to neurological, neoplastic and respiratory disorders ${ }^{(11)}$. Whereas other studies done on patients hospitalized in the ICU $U^{(12-13)}$ and hospital units ${ }^{(12)}$, showed that cardiovascular disorders were predominant.

When observing the access routes used for administering enteral nutrition, the ones most frequently used were oro/nasogastric, gastronomy and jejunostomy, with gastric positioning. In the literature ${ }^{(11-12)}$ a higher prevalence of nasoenteral feeding tubes was seen (95\%), with post-pyloric 
Table 2. Absolute and relative distribution of patients by hospitalization unit according to frequency of inadvertent exit of the enteral feeding tube. Santa Maria/RS, 2012.

\begin{tabular}{lcccc} 
Variable & $\begin{array}{c}\text { Patients with en- } \\
\text { teral feeding tube } \\
(\mathbf{N}=\mathbf{4 6})\end{array}$ & $\begin{array}{c}\text { Patients with inadvertent } \\
\text { exit of the enteral feeding } \\
\text { tube }(\mathbf{N = 2 0 )}\end{array}$ & $\begin{array}{c}\text { Inadvertent exits of the } \\
\text { enteral feeding tube } \\
\text { (N=39) }\end{array}$ & p* \\
\cline { 2 - 4 } & $\mathbf{N}(\%)$ & $\mathbf{N}(\%)$ & $\mathbf{N}(\%)$ & 0.287 \\
Hospitalization units & & & & \\
Medical Clinic & $27(58.7)$ & $14(51.9)$ & $72(82 \%)$ & $7(18 \%)$ \\
ICU & $19(41.3)$ & $6(31.6)$ & \\
\hline
\end{tabular}

Source: Research data.

* Pearson Chi-squared test with continuity correlation

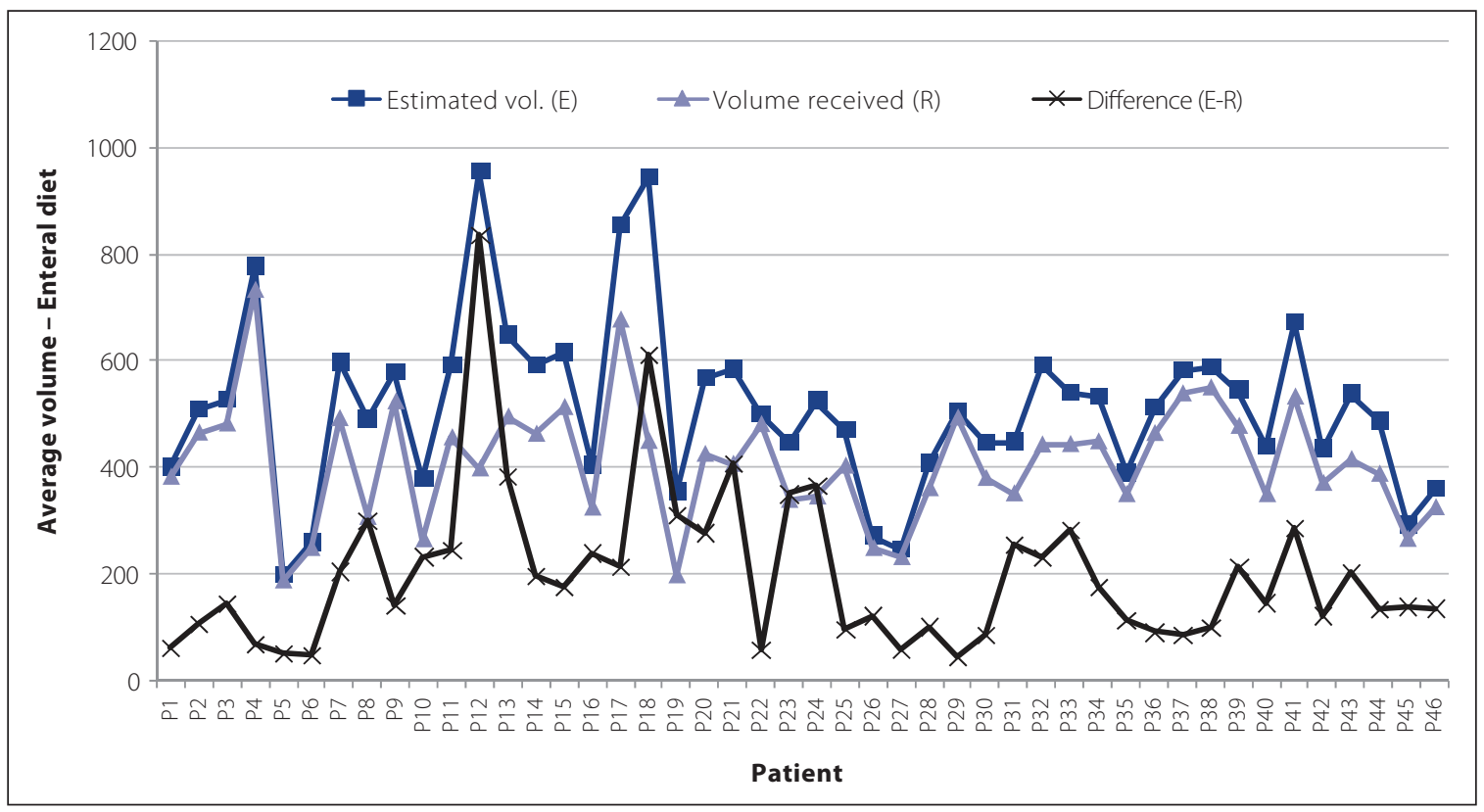

Graph 1. Evolution of the average volumes (estimated, received and difference) of the enteral diet by patient on the days of evaluation. Santa Maria/RS, 2012. (N=46)

Source: Research Data

positioning. In one study ${ }^{(13)}$ the use of nasogastric feeding tubes was predominant (83\%). There was no proven advantage to the post-pyloric instead of gastric positioning, but the choice of position of the feeding tube depends on whether or not the patient was at a risk for aspiration or intolerance, such as distension, reflux or gastroparesis ${ }^{(14)}$.

Evaluation of the infusion of the diet and the characteristics of the skin at the feeding tube insertion site showed that the continuous infusion complies with that recommended by the institution (done by infusing pump), and the skin (nose, mouth, face, abdomen) was free from lesions. Lesions, when they occur, are a result of improper positioning and the adhesive tapes used to secure the feeding tube. Accordingly, periodic assessment and daily changing of the site for securing the feeding tube are important procedures for avoiding adverse events. Signals, such as hyperemia, traction, humidity, friction and discomfort reported by the patient must be considered ${ }^{(14)}$.

The use of the Infusion Pump for EN helps with continuous and regular administration, without oscillations in the volumes infused. The standard equipment for administering EN, which is blue, identifies use only for infusion of enteral diets. This aspect, combined with the fact that it is not suitable for devices other than the feeding tube, are 
strategies that are important for reducing safety incidents related to ENT.

The average time for hospitalization at each one of the units studied was greater than that seen in other studies (06 to 13.7 days $)^{(15-16)}$. While the patients were being monitored, adverse events related to the obstruction and inadvertent exit of the feeding tube were seen, as were events related to the infused volume of the diet. The rate of incidence of obstruction of the feeding tube $(0.021$ for 100 patients using an EFT) is in line with the target proposed by ILSI-Brasil, which is $<5 \%(2)$. A similar incidence $(0.028)$ was seen in a study done with elderly patients hospitalized in the ICU(15).

Obstruction of the feeding tube is one of the most common mechanical complications in patients that use $E N$, which may occur due to lack of irrigation with water before and after medication is administered, precipitation of the diet, and bends and kinks in the tubing ${ }^{(14)}$. Furthermore, the simultaneous use of medication and EN may lead to reduced bioavailability of the drug and obstruction of the feeding tube ${ }^{(16)}$.

With relation to hydration, individual calculation of the hydration needs for each patient is fundamental for maintaining and recovering one's health. The daily-recommended water intake, for adults between 18 and 55 years old, is $35 \mathrm{ml} / \mathrm{kg} /$ day, for people who are between 55 and 65 it is $30 \mathrm{ml} / \mathrm{kg} /$ day and for those over 65 it is $25 \mathrm{ml} / \mathrm{kg} /$ day ${ }^{(17)}$.

It is worth highlighting that the approximate quantity of free water in the industrialized enteral diets with a caloric density of 1.0 to $1.2 \mathrm{kcal} / \mathrm{ml}$ is 0.84 to $0.86 \mathrm{ml}$ of $\mathrm{H}_{2} \mathrm{O}$ / $\mathrm{ml}$ of the diet, in those with $1.5 \mathrm{kcal} / \mathrm{ml}$ it is $0.76 \mathrm{ml} \mathrm{of} \mathrm{H}_{2} \mathrm{O}$ / $\mathrm{ml}$ and in those with a density of $2.0 \mathrm{kcal} / \mathrm{ml}$ it is $0.57 \mathrm{ml}$ of $\mathrm{H}_{2} \mathrm{O} / \mathrm{ml}^{(17)}$. Thus, when the caloric density is higher, the quantity of water supplied by the diet is lower. Knowing this, it becomes necessary to observe the balance of water and clinical conditions of the patient, in order to identify the need to supply additional water by infusion using the feeding tube, or through intravenous hydration, principally in unconscious and debilitated patients.

The rate of incidence of inadvertent exit (4.6\%) was higher than that seen in another study (3.6\%) ${ }^{(12)}$, but it is inline with those recommended for the ICU, which must be $<5 \%$ and for the hospital units $<10 \%{ }^{(2)}$.

The Medical Clinic unit was the one that presented the highest number of patients with inadvertent exits of the EFT ( $n=14 ; p=0.287$ ). This may be related to that fact that it is an open unit, with the nursing staff distributed throughout more than one ward, which hinders constant surveillance, such as that done in the ICU. It must also be taken into account that patients of the ICU spend more time sedated. The workload, the lack of workers and the complexity of the care may contribute to the occurrence of these events.

Evidence of ingestion of the diet at a volume that is less than that which is estimated, is similar to other stud$i^{(9,13)}$ and it is lower than another ${ }^{(6)}$, which showed higher averages, since the patients received an average of $428 \mathrm{ml}$ $( \pm 243 \mathrm{ml} /$ day) less, i.e., they did not receive $40 \%$ of the volume prescribed ${ }^{(6)}$.

One study ${ }^{(18)}$ showed that the principal reasons for interruption of EN were: reflux, medical and nursing procedures, diarrhea, abdominal distension, problems with the feeding tube, nausea and vomiting. In another investigation ${ }^{(11)}, 39 \%$ of the complications were related to delay of the diet, gastrointestinal problems (22\%), surgeries and exams (21\%), obstruction of the feeding tube (10\%) and physical therapy procedures (8\%). In surgical patients, the reasons for suspension included fasting for procedures (84.6\%), and nausea and vomiting (38.5\%) $)^{(19)}$. In ICU patients, fasting was responsible for $41.6 \%$ of pauses of $\mathrm{EN}^{(6)}$. In addition to these reasons, other findings included: constipation $(8.8 \%)^{(16)}$, reflux (15\%), gastric residue (7.5\%) and pulmonary aspiration $(2.5 \%)^{(13)}$. In this study, 41 patients (89.13\%) had the diet suspended for at least one day.

Here we have a problem that is extremely relevant in the hospital setting, but not always easily identified, which is in-hospital malnutrition caused by an inadequate supply of the diet. Its occurrence is harm generated while providing healthcare, i.e., an adverse event, since improper nutrition can aggravate the patient's condition, increase hospitalization time and elevate mortality rates ${ }^{(20)}$.

With this, the findings related to laboratory exams deserve further investigation, since, despite not having a correlation with the administered volume of the diet, may indicate the existence of other aspects not investigated in this study, considering the frequency of patients with alterations in these exams.

\section{CONCLUSIONS}

We have concluded that, despite the fact that the rates of incidence of obstruction (2.1\%) and inadvertent exit of the feeding tube (4.6\%) are in accordance with what has been recommended, the results indicate the need to review multi-disciplinary healthcare practices, since in 54.8\% of the cases the diet was suspended to perform exams or procedures.

Another relevant aspect of this study was the verification that all the patients experienced loss when receiving the daily volume of the diet. There was no correlation between the laboratory exam results, however, this finding 
may be masked by the small size of the sample (an aspect considered as a limitation of the study).

The data presented herein may serve to provide support for healthcare services, and compose the theoretical framework used by the institution's Multi-professional Nutritional Therapy Team in the sense that it supports strategies to guarantee the effectiveness of NT for patients who use feeding tubes. It may also contribute to solidifying the use of quality indicators for a diagnosis of reality and implementation of improvements that result in minimizing adverse events related to ENT.

\section{口EFERENCES}

1. Garita FS, Cukier C, Magnoni D. Indicações e prescriçãa da terapia nutricional. In: Matusuba CST, Magnoni D, organizadores. Enfermagem em terapia nutricional. São Paulo: SARVIER; 2009. p. 35-55.

2. Waitzberg DL, Bottoni A, Lopes ARC, Freire ANM, Bottoni A, Mirandola A, et al. Indicadores de qualidade em terapia nutricional: apresentação. In: Waitzberg DL, coordenador geral. Indicadores de qualidade em terapia nutricional. São Paulo: ILSI Brasil; 2008. p. 21-25.

3. Duarte IG, Nagai MH, Mota NVVP, Bittar OJNV, Nishikuni YY. $3^{\circ}$ Caderno de Indicadores/ Compromisso com a Qualidade Hospitalar (CQH) [Internet]. 1 ed. São Paulo(SP): APM/CREMESP, 2009 [citado 2013 mar 15]. Available in: http:// www.cqh.org.br/files/3\%20caderno\%20de\%20ind\%20baixa-res.pdf.

4. Tronchin DMR, Reis EAA, Gerolin FSF, Nunes IA, Ferrero LHV, Melleiro MM et al. Manual de indicadores de enfermagem NAGEH / Compromisso com a Qualidade Hospitalar (COH) [Internet]. 2 ed. São Paulo(SP): APM/CREMESP, 2012 [citado 2013 mar 15]. Available in: http://www.cqh.org.br/portal/pag/doc.php?p_ndoc=125.

5. Aranjues AL, Teixeira ACC, Caruso L, Soriano FG. Monitorização da terapia nutricional enteral em UTI: indicador de qualidade? Mundo saúde [Internet]. 2008 [citado 2013 jan 15];32(1):16-23. Available in: http://www.saocamilo-sp.br/ pdf/mundo_saude/58/16a23.pdf.

6. Assis MCS, Silva SMR, Leães DM, Novello CL, Silveira CRM, Mello ED, et al. Nutrição enteral: diferenças entre volume, calorias e proteínas prescritos e administrados em adultos. Rev. bras. ter. intensiva [Internet]. 2010 [citado 2013 jan 20];22(4):346-50. Available in: http://www.lume.ufrgs.br/bitstream/handle/10183/29442/000769274.pdf? sequence $=1$.

7. Teixeira ACC, Caruso L, Soriano FG. Terapia nutricional enteral em unidade de terapia intensiva: infusão versus necessidades. Rev. bras. ter. intensiva [Internet]. 2006 [citado 2013 jan 15];18(4):346-50. Available in: http://www.scielo. $\mathrm{br} / \mathrm{pdf} / \mathrm{rbti} / \mathrm{v} 18 \mathrm{n} 4 / 03 . \mathrm{pdf}$.

8. Cartolano FC, Caruso L, Soriano FG. Terapia nutricional enteral: aplicação de indicadores de qualidade. Rev. bras. ter. intensiva [Internet]. 2009 [citado 2013 jan 15];21(4):376-83. Available in: http://www.scielo.br/pdf/rbti/v21n4/ v21n4a07.pdf.

\section{Author's address:}

Anamarta Sbeghen Cervo

Rua Waldemar Simões Cavalheiro, 25, Camobi

97110-810, Santa Maria, RS

E-mail: anamarta67@yahoo.com.br
9. Oliveira NS, Caruso L, Soriano FG. Terapia nutricional enteral em UTI: seguimento longitudinal. Nutrire Rev. Soc. Bras. Aliment. Nutr [Internet]. 2010 [citado 2013 fev 20];35(3):133-48. Available in: http://files.bvs.br/ upload/S/1519-8928/2010/v35n3/a1766.pdf.

10. Ministério da Saúde (BR). Portaria no 529, de $1^{0}$ de abril de 2013. Programa Nacional de Segurança do Paciente (PNSP). Diário Oficial da República Federativa do Brasil [Internet]. 2013 [citado maio 2013]. Available in: http://www. aeciherj.org.br/docs/portaria-529_2013.pdf.

11. Campanella LCA, Silveira BM, Neto OR, Silva AA. Terapia nutricional enteral: a dieta prescrita é realmente infundida? Rev. bras. nutr. clín [Internet]. 2008 [citado 2013 jan 15]; 23(1):21-5. Available in: http://disciplinas. stoa.usp.br/pluginfile.php/55798/mod_resource/content/1/Dieta\%20 enteral.pdf.

12. Graciano RDM, Ferretti REL. Nutrição enteral em idosos na Unidade de Terapia Intensiva: prevalência e fatores associados. Rev. bras. geriatr. gerontol [Internet]. 2009 [citado 2013 jan 15];2(4):151-55. Available in: http://www.sbgg.org.br/ profissionais/arquivo/revista/volume2-numero4/artig004.pdf.

13. Detregiachi CRP, Quesada KR, Marques DE. Comparação entre as necessidades energéticas prescritas e administradas a pacientes em terapia nutricional enteral. Medicina (Ribeirão Preto) [Internet]. 2011 [citado 2013 jan 15];44(2):17784. Available in: http://revista.fmrp.usp.br/2011/vol44n2/A0_Terapia\%20 nutricional\%20enteral\%20em\%20pacientes\%20hospitalizados.pdf.

14. Nunes ALB, Koterba E, Alves VGF, Abrahão V, Correia MITD. Terapia nutricional no paciente grave. In: Jatene FB, Bernardo WM, coordenadores. Projeto Diretrizes. São Paulo: Associação Médica Brasileira e Coselho Federal de Medicina; 2011. p. 309-19.

15. Serpa LF, Fini A, Faintuch J. Complicações e condutas em terapia nutricional. In: Matsuba CST, Magnoni D. Enfermagem em terapia nutricional. São Paulo: SARVIER; 2009. p. 163-82.

16. Oliveira NS, Caruso L, Bergamaschi, DP, Cartolano FC, Soriano FG. Impacto da adequação da oferta energética sobre a mortalidade em pacientes de UTI recebendo nutrição enteral. Rev. bras. ter. intensiva [Internet]. 2011 [citado 2013 fev 20];23(2):183-89. Available in: http://www.scielo.br/pdf/rbti/v23n2/ a11v23n2.pdf.

17. Silva LD, Lisboa CD. Consequências da interação entre nutrição enteral e fármacos administrados por sondas: uma revisão integrativa. Cogitare Enferm [Internet]. 2011 [citado 2013 fev 20];16(1):134-40. Available in: http://ojs.c3sl.ufpr. br/ojs2/index.php/cogitare/article/view/21124/13950.

18. Martins C., Cardoso SP. Nutrição por sonda. In: Terapia nutricional enteral e parenteral: manual de rotina técnica. Curitiba: Nutroclínica; 2000. p. 95-191.

19. Fugino V, Nogueira LABNS. Terapia nutricional enteral em pacientes graves: revisão de literatura. Arq Ciênc Saúde [Internet]. 2007 [citado 2013 jan 15];14(4):220-26. Available in: http://www.cienciasdasaude.famerp.br/racs_ ol/vol-14-4/ID248.pdf.

20. Cervo AS. Eventos adversos em terapia nutricional enteral [dissertação]. Santa Maria (RS): Programa de Pós-Graduação em Enfermagem, Universidade Federal de Santa Maria (RS); 2013.

Received: 05.09.2013

Approved: 17.03.2014 